\title{
Analytic Theology and the Richness of Classical Theism: An Interview with Eleonore Stump
}

\section{La Teología analítica y la riqueza del teísmo clásico. Una entrevista con Eleonore Stump}

\author{
Agustín ECHAVARRía \\ Universidad de Navarra. Facultad de Filosofía y Letras \\ Pamplona. España \\ aechavarria@unav.es

\section{Eleonore STUMP} \\ Saint Louis University. Robert J. Henle Professor of Philosophy \\ St. Louis, MO. EE.UU. \\ stumpep@slu.edu
}

Resumen: En esta entrevista la Profa Eleonore Stump habla acerca de las causas por las que dentro de la tradición analítica ha surgido la Teología Analítica. Trata también de las ventajas de mantener la visión tradicional de la teología del ser perfecto con respecto a los atributos divinos, así como de la importancia de la narrativa bíblica para afrontar el problema del dolor. Finalmente pone de manifiesto la importancia de la implicación de la universidad en el estudio de la teología filosófica.

Palabras clave: Teología Analítica, Simplicidad divina, Sufrimiento y mal.
Abstract: In this interview Prof. Eleonore Stump speaks about the causes of the emergence of Analytic Philosophical Theology within the analytic tradition; the advantages of maintaining the traditional picture of perfect being theology with regards to divine attributes; her conception about the importance of biblical narratives in facing the problem of suffering; and the importance of university involvement in research on philosophical theology.

Keywords: Analytic Theology, Divine Simplicity, Suffering and Evil. 
O n April 20-21, 2015, Prof. Eleonore Stump ${ }^{1}$ visited the University of Navarra, where she delivered two lectures as a part of the activities of the Cluster Group on Analytic Theology, «Philosophical and Theological perspectives on Divine Providence», held in the Philosophy Department and supported by a grant from the John Templeton Foundation funded project «Analytic Theology» of the Centre for Philosophy of Religion (University of Notre Dame). Prof. Agustín Echavarría, together with Prof. Martín Montoya, took the opportunity to have a conversation with Prof. Stump, about many different philosophical and theological topics. The conversation began with a reflection on the causes of the emergence of the new Analytic Philosophical Theology within the analytic tradition. Prof. Stump continued by describing the advantages of holding the traditional picture of perfect being theology with regards to divine attributes, something many analytic philosophers are prone to reject. She then explained the importance of biblical narratives in facing the problem of suffering, to end highlighting the importance of university involvement in research on philosophical theology.

Agustín Echavarría: God seems to have a profound sense of irony, making the more important movement of revival of philosophical and theological reflection emerge from analytic philosophy, a tradition which once was dominated by logical positivism's strong anti-metaphysical imprint. In the meantime, the Continental tradition, apparently more sympathetic to metaphysics, has become seemingly sterile when it comes to rational discourse about God. What do you consider to be the causes of this a priori unlikely phenomenon?

Eleonore Stump: Well, first let me say how pleased I am to be here, and how much I have enjoyed getting to know the University. I am very impressed by what the philosophers are doing here in the Analytic Theology Project, and

${ }^{1}$ Prof. Eleonore Stump is the Robert J. Henle Professor of Philosophy at Saint Louis University, where she has taught since 1992. She received a B.A. in classical languages from Grinnell College (1969), where she was valedictorian and received the Archibald Prize for scholarship; she has an M.A. in Biblical Studies (New Testament) from Harvard University (1971), and an M.A. and $\mathrm{PhD}$ in Medieval Studies (Medieval Philosophy) from Cornell University (1975). Before moving to Saint Louis University, she taught at Oberlin College, Virginia Polytechnic and State University, and Notre Dame. Currently, she also holds secondary or honorary appointments at Wuhan University and Australian Catholic University. She has published extensively in medieval philosophy, philosophy of religion, and contemporary metaphysics. Her books include her major study Aquinas (Routledge, 2003) and her extensive treatment of the problem of evil, Wandering in Darkness: Narrative and the Problem of Suffering (Oxford, 2010). 
I will be glad to say so to my colleagues when I am home. I enjoyed my lecture today very much, and I thought that the questions I received after my lecture were very smart and very interesting.

As for the question that you ask in such an elegant and amusing way, whether God has a sense of irony in letting Analytic Theology be a discovery made by those philosophers in the Analytic Tradition who once rejected even metaphysics, to say nothing of religion. This is a good question; this is definitely a good question. But I would say it is not entirely true that the Continental tradition is sterile in this regard. There are certainly people highly trained in the Continental tradition who are making their mark in Analytic Theology. So, to take just one example, in Munich there is now a marvelous project in Analytic Theology which is being run by Fr. Godehard Brüntrup, S.J., who is himself well trained in the Continental tradition. So, both Continental theology and philosophy are participating in this resurgence of interest in philosophical theology, philosophy of religion, and so on. But it is still true, as you said, it is still true that the main force here has been on the part of the analytic philosophers, who did at one time reject even metaphysics. So, why would this be? That's your question: how did this happen?

I would say that even in the days when it rejected metaphysics, Analytic Philosophy was committed to careful reasoning, to thoughtful precise pursuit of truth in reasoning. When you pursue truth in careful and reflective ways, you can be astonished to discover where it will take you. What Catholics think is that the Second Person of the Trinity is Truth; and if you are careful in your love of reason, and your love of truth, that is where you will find yourself. So that is one way, but of course not the only way, of understanding what has happened in Analytic Theology.

AE: The past few decades have seen a growing interest of trained analytic philosophers on theological issues that have given place to the emergence of the so-called «analytic theology». Continental theologians either seem reluctant to engage with this movement or are simply unaware of its existence. Why do you think this is the case and how do you think this situation could change?

ES: Well, here too I have to nuance the question a little bit, because there are marvelous projects in Analytic Theology, not only at Munich, but also I would say at Augsburg, at Innsbruck, at Mainz, and Frankfurt, and many other places as well. So, Continental theologians are gaining an interest in this project, and they are certainly participating in it. But it still remains the case, 
I think, that there are Continental scholars in the tradition of Kant, say, who find the project infuriating and that's because in a sense for a long time they had been thinking that we couldn't, in fact, think of God in what they considered was an old-fashioned Thomistic way. And the idea that there are now some very smart people who want to resuscitate what had seemed dead for some time was very annoying in consequence. If you think you have won the battle only to discover that you have to fight the fight all over again, that can make you very annoyed.

So, I understand why to some theologians it seems inconceivably stupid and annoying that outsiders should come into their territory and bring with them these Thomistic approaches, or philosophical approaches, or Analytical approaches.

On the other hand, Continental theologians and Analytic theologians are not natural enemies. Rather, they are natural allies. So, like Analytic philosophers, Analytic theologians are committed to careful precise reasoning. But the more careful your reasoning is, the more you will have to focus on what is small. And what Continental theologians have always been interested in is seeing the whole forest, seeing the big picture. So, if these two groups of Continental theologians and Analytic theologians can work together, then one group can help the other group broaden its focus and consider the whole forest, and one group can help the other group to pay careful attention to the details, to the trees in that forest. And together they can do a very good work.

AE: Besides your work on analytic philosophy of religion, you have a long track record of scholarship on classical Christian authors such as Boethius ${ }^{2}$ and Aquinas ${ }^{3}$. To what extent do you think that knowledge of the Western tradition of philosophy and theology can contribute to the contemporary debate on analytic philosophy of religion?

2 See, for instance, STump, E., «Boethius's Works on the Topics», Vivarium 12 (1974) 77-93; «Hamartia in Christian Belief: Boethius on the Trinity», in Hamartia: The Concept of Error in the Western Tradition, Lewiston, NY: Edwin Mellen Press, 1983, 131-148; «Boethius's In Ciceronis Topica and Stoic Logic», in WIPPEL, J. (ed.), Studies in Medieval Philosophy, Washington: Catholic University Press, 1987, 1-22.

3 See, for instance, Stump, E. and Kretzmann, N. (eds.), The Cambridge Companion to Aquinas, Cambridge: Cambridge University Press, 1993; Stump, E., Aquinas, London and New York: Routledge, 2003; «Aquinas's Account of Freedom: Intellect and Will», The Monist 80 (1997) 576597; «Aquinas's Virtue Ethics and its Metaphysical Foundation» in J. SZAIF and M. LuTZ BACHMANN (eds.), Was ist das für den Menschen Gute? What is good for a buman being?, Berlin and New York: Walter de Gruyter, 2004, 209-228. 
ES: I would say that it is important always to understand that expertise is vested in a community. So, if you have breast cancer and your doctor thinks that watermelon could cure your breast cancer, you should get a different doctor. You want your doctor to work within the great community of the Western medical profession. You do not want your doctor to work in isolation.

In the same way, if you decide you want to learn biology, but you don't want to learn it from anybody else, you just want to make up biology for yourself, starting all by yourself, what we all know is that you'll come up with nothing. It is a stupid enterprise. Most of what we know that is worthwhile we have received from others. And this is true not just for individuals but also for whole communities. The current community of biologists has received much that is valuable from the communities of scientists that went before. If they had not done so, biology would not be where it is today.

So this is how it is in ordinary life for individuals, and this is how it is in the sciences, and this is also how it is in culture broadly speaking. So, when Mao Tse Tung cut the Chinese off from their great heritage, when he forbade the great classic Chinese novels, he weakened the Chinese people. A community cut off from its heritage is going to be weakened and is going to suffer for that weakness. This is the way it is also in theology. For two millennia or more, the West has put some of its best and brightest minds to work in philosophy and theology. Not to learn from their efforts is foolish. It's not that they have everything right. They don't. But over the course of centuries, they taught one another where the dead ends were, where the wrong moves are. And not to learn from them is just as foolish as going to the doctor who doesn't learn from the medical community around him but instead thinks watermelon could cure cancer.

AE: You have defended over the years a classical view of God as a perfect being, emphasizing some attributes many philosophers of religion are prone to reject as problematic, for instance, divine simplicity ${ }^{4}$. What advantages do you find in keeping

\footnotetext{
${ }^{4}$ Stump, E. and Kretzmann, N., «Absolute Simplicity», Faith and Philosophy 2 (1985) 353-382; Stump, E., «Simplicity», in Taliaferro, Ch. and QuinN, P. (eds.), Companion to Philosophy of Religion, Oxford: Blackwell Publishing, 1997, 250-256; «Eternity, Simplicity, and Presence», in Doolan, G. T. (ed.), The Science of Being as Being: Metaphysical Investigations, Washington, DC: Catholic University of America Press, 2011, 243-263; «God's Simplicity», in DavIES, B. and STump, E. (eds.), The Oxford Handbook of Aquinas, Oxford: Oxford University Press, 2012, $135-$ 146; STump, E., The God of the Bible and the God of the Philosophers, Milwaukee, Wisconsin: Marquette University Press, 2016.
} 
the image of classical theism with regards to divine attributes, and more specifically, simplicity?

ES: There are some philosophers who thought we had to abandon those classical divine attributes, because accepting them was religiously pernicious. So, Al Plantinga has said, in his Aquinas Lecture at Marquette University, that no God who is simple could do anything. Such a God could not create and could not love, because, as Plantinga thought, on the doctrine of simplicity God is being itself, and being itself cannot care about you, or scold you, or love you, or create you. But I think that these divine attributes look religiously pernicious to some people, such as Al Plantinga, because they are misunderstood. For sure and certain, if I thought the doctrine of simplicity meant that God is only Being, and that as Being God could not love you, I would want to throw the doctrine of God's simplicity out, too. But that is not what the doctrine of simplicity means.

Instead, in my view, the doctrine of simplicity does this. It combines the greatest power of the Greek tradition with the greatest power of the Jewish tradition to make a highly unusual philosophical worldview, which is Christianity's. That worldview works this way. The ultimate foundation of all reality for the Greeks, for Plato, say, is the form of the Good, or for Parmenides, Being. So understood, the ultimate foundation of reality has something selfexplanatory about it, and it can also explain other things in the world. That is where the power of Greek thought lies. But for the Jews the ultimate foundation of all reality is a person - a person with power, mind, will, love, and care. That person can scold you, or punish you, or love you, or talk to you, or cajole you, or invite you to himself.

And in the very early period, drawing on both these great traditions, what Christianity did was to marry these traditions. Christianity held that the ultimate foundation of all reality is being itself, self-explanatory being itself, which is also, in ways we cannot understand, also something with a mind and a will, something capable of loving you. So what we have in the Christian tradition in the doctrine of simplicity is something like Quantum Theology. Consider light. What is light? It's a wave. It's a particle. Ok, it is both. All right, none of these answers is right. In fact, we don't know what light is; but sometimes we have to talk about it as a wave, and sometimes we have to talk about it as a particle. And that is as close as we can get to understanding the foundation of all reality in physics.

Analogous points apply to theology. What is God? God is an entity. God is being itself. Ok, God is both. All right, none of these answers is right either. 
In fact, we don't know the quid est of God either. But sometimes we have to talk about God as Love, and sometimes we have to talk about God as loving - and then we have Quantum Theology. This approach to the ultimate foundation of metaphysical reality has great explanatory power. And when you leave it out of your worldview, sooner or later, somewhere in your philosophy you are going to come up against a mess. And so the doctrine of simplicity is a powerful foundation for theology, in my view.

AE: In your book Wandering in Darkness ${ }^{5}$ you use biblical narratives as a way to explore the problem of suffering. Could you explain what kind of insight this methodology provides and how can it improve the philosophical discourse concerning buman suffering?

ES: It seems to me clear that there is a kind of knowledge which is a knowledge of persons. It is direct, immediate, intuitive and non-propositional, in the way perception is. But, instead of giving you cognition of extra-mental, perceptible objects, it gives you a kind of mind-reading cognition of persons and their mental states. This is a marvelous kind of cognition, which even infants have from birth. This mind-reading cognition is necessary for infants to learn language and for them to become typically functioning in their development. When this cognitive capacity is impaired, autism can result. So, this cognitive capacity which we have from birth, and which produces in us a nonpropositional cognition of persons, this is a cognition which we can share with each other through stories. Consider, for example, what happens if my son says to me «Mom, I've met someone, and you need to like her». Then, however long he talks to me about this young woman, I still want to see her. And when I see her, I gain a great deal of knowledge about her. Furthermore, what I learn by meeting her I can share with my husband by telling him stories about her. So, stories give us a kind of access to a part of reality that matters to us greatly in human life for everything that has to do with persons. Some of what we learn through stories we might be able to communicate without stories, but some of it not. Some of it we can't communicate without stories, or without direct second-personal experiences. So if we are doing philosophy about something where persons matter a very great deal, then, in that case, we really do need stories to do the philosophy well. In the case of the problem of

5 STump, E., Wandering in Darkness: Narrative and the Problem of Suffering, Oxford: Oxford University Press, 2010. 
suffering in particular, the question is how could a perfectly good, omniscient, omnipotent God let some human person suffer. This is a question where persons are at the very center of the perplexity, and so stories have something to contribute that we are not going to get without the stories.

$\mathrm{AE}$ : If God is omnipotent and benevolent, why does He permit horrendous evils? Can any Theodicy give a proper account of things like the suffering of innocent children?

ES: Well, the first thing that has to be said is that when we are talking about the problem of evil, we have to remember that what we are talking about is suffering. Suffering in its nature is horrible, lamentable, heartbreaking. It is up to us to do whatever we can to stop it. Nothing about finding a theological explanation of suffering alters those facts. It is crucial to keep these things in mind, so that we do not lose our humanity in the philosophical discussion.

For the same reasons, you must not think that if you have found an explanation for why God allows suffering, then you've found an explanation that explains suffering away. What your explanation explains is suffering, and suffering remains heartbreaking, no matter what the explanation for it is. So that's the first point. And then I would say everything depends on the context in which you ask the question about the problem of evil. To see this point, imagine that there is an alien named Max. And imagine that on Max's world nobody is ever sick, nobody ever dies, and everybody lives forever in one building - and that's it. Outside the building there is simply nothing at all. Max's whole world is one building. And now suppose we show Max a video of a human hospital. Then this is what Max will see. People in the hospital are cut open by doctors with knives; they are jabbed by doctors with sharp instruments. They are given poisonous drugs by doctors. And Max will say, «How could those doctors inflict this kind of suffering on these poor innocent people?» Now you can imagine trying to explain it to Max. We will say, «Well, Max, see, these people are actually really sick». And Max will say: « Sick?! They are sick, all right! But they are sick because of what the doctors do to them. They looked fine when they first started out in the hospital. And after the doctors cut them open with knives, they look horrible». We can say: «No, no, Max. The doctors are just trying to heal them». And then Max will say: «Oh, yeah? That's your idea of healing? You slice people open with these knives? You, give them poison to eat? This is your idea of how they will be healed?».

We will say: «Well, but Max, you just can't see their sickness. They had a sickness when they came in, and the doctors are just trying to make them 
better, so they can go on to live longer». And then Max will say: «Live longer? People die in that hospital. I've seen it in the video. Lots of people die in the hospital». And then we will say: «It is true that some people die in the hospital. But a lot of people don't die. They go on to live. They leave the hospital and live for a long time afterwards». Then Max will say: «Are you trying to tell me that in order to show that the doctors are good you have to postulate life outside the building? Even you have to grant that that's an incredible way of having to show that the doctors are good».

And now you see the problem. What Christianity says is there is in all of us a most horrible sickness. Even those who look most innocent simply are without symptoms, but the disease is lurking inside and will surely kill them with a lingering everlasting second death, unless something comes to heal them. The Christian tradition has always thought that suffering is part of God's medicine for the brokenness, the internal alienation, the willed loneliness that afflicts all people in the post-Fall human condition. To say this is not to say that those who suffer more are worse than other people. On the contrary, it is to say that they are better and healthier. In the hospital, the ones who are given the strongest chemotherapy are the healthiest. The ones who get nothing are the ones whose disease is so advanced that they are terminally ill. On Christian thought, those who suffer are the beloved of God, who have a chance at glorious health through the suffering that afflicts them.

AE: What are the perspectives and main lines of research for the future years in the field of Analytic Theology?

ES: To tell you the truth, I would say, that what they are is what people like you will make them to be. So, where the field goes is a function of those who work in the field, who bring their interests, their temperaments, their training to bear. So, those people who work in the field, who give their life to these questions and this labor, they will determine where it goes. So it is up to you and your generation to help decide where this field goes. And I'm sure that in your hands, it will go some place wonderful. I look forward to seeing where you take it.

AE: Finally, why is it still important today for universities to embrace and invest in research on philosophical theology?

ES: Well, what do you actually want your University to do, and what do you want to do with your life? Do you want to make more of a wreck of the 
Earth? Do you want to make technological advances without understanding what you are doing, or where those advances are going? What do you want to encourage people to do? Make money? Spend their lives in some kind of unfulfilling career? For that matter, what is the point of anything? What is the point of having a University? Why don't we blow it up and all go off to play golf? There is a lot of labor in being an academic; although not everybody outside the University sees it, there is. It takes an immense discipline to be part of a University. Why should we engage in this discipline? We could just watch television, or even just do nothing. There has to be answer to this question: what's the point of it all? In the end, every human heart wants and needs to know: Why am I doing this? Why should I care about this? What should I care about? And then you can go off and try to think about these questions on your own, as an isolated individual, or you can join the great community of humankind which has thought about these issues for generation after generation, and you can learn together in community from the experts, in ways that will deepen and enrich your life forever. If the University doesn't find that effort worthwhile, well then what will anyone find worthwhile? 


\section{Bibliography}

STump, E., Aquinas, London and New York: Routledge, 2003.

STUMP, E., «Aquinas's Account of Freedom: Intellect and Will», The Monist 80 (1997) 576-597.

STUMP, E., «Aquinas's Virtue Ethics and its Metaphysical Foundation», in SZAif, J. and LutZ BACHMAnN, M. (eds.), Was ist das für den Menschen Gute? What is good for a buman being?, Berlin and New York: Walter de Gruyter, 2004, 209-228.

STUMP, E., «Boethius's In Ciceronis Topica and Stoic Logic», in WipPEL, J. (ed.), Studies in Medieval Philosophy, Washington: Catholic University Press, 1987, 1-22.

STUMP, E., «Boethius's Works on the Topics», Vivarium 12 (1974) 77-93.

Stump, E., «Eternity, Simplicity, and Presence», in Doolan, G. T. (ed.), The Science of Being as Being: Metaphysical Investigations, Washington, DC: Catholic University of America Press, 2011, 243-263.

Stump, E., «God's Simplicity», in Davies, B. and Stump, E. (eds.), The $O x$ ford Handbook of Aquinas, Oxford: Oxford University Press, 2012, 135-146.

STUMP, E., «Hamartia in Christian Belief: Boethius on the Trinity», in $\mathrm{Ha}$ martia: The Concept of Error in the Western Tradition, Lewiston, NY: Edwin Mellen Press, 1983, 131-148.

StumP, E., «Simplicity», in Taliaferro, Ch. and Quinn, P. (eds.), Companion to Philosophy of Religion, Oxford: Blackwell Publishing, 1997, 250-256.

Stump, E., The God of the Bible and the God of the Philosophers, Milwaukee, Wisconsin: Marquette University Press, 2016.

Stump, E., Wandering in Darkness: Narrative and the Problem of Suffering, Oxford: Oxford University Press, 2010.

Stump, E. and Kretzmann, N., «Absolute Simplicity», Faith and Philosophy 2 (1985) 353-382.

Stump, E. and KretzMann, N. (eds.), The Cambridge Companion to Aquinas, Cambridge: Cambridge University Press, 1993. 
